\title{
How much does rice price influence milled paddy price? Analysis of price integration in Indonesia
}

\author{
Yogi Makbul \\ Institut Teknologi Bandung \\ Sudrajati Ratnaningtyas \\ Institut Teknologi Bandung
}

\begin{abstract}
This study analysis how much the price of rice influences the price of milled paddy. The results can aid in policy suggestions related to the price of rice. If the price of rice has a big impact on the price of milled paddy, increasing rice prices could be an effective policy to increase the price of milled paddy. This would desire farmers to increase production and create food security. If is the little effect, this policy would not be effective. The impact of this policy might harm consumers and increase poverty. The analysis was carried out using price integration and data from Indonesia. The data were taken from January 1, 2007, to December 31, 2014. The results show that rice prices influence the price of milled paddy, but not proportionally since increases in milled paddy price are always lower than increases in rice prices. Thus, increasing the price of rice to increase the price of milled paddy to help the farmers is not effective because it does not substantially increase farmer income and will not be effective for stimulating production. This phenomenon occurs because for many farmers (especially small farmers), the market structure is nearly a monopsony market. As a suggestion for make increasing rice prices more effective, the government could intervene via Indonesian logistics Bureau to make the market more competitive. This intervention could create competition for traders in the monopsony market.
\end{abstract}

Keywords: The price of rice, the price of milled paddy, the integration of price, food price policy.

\section{INTRODUCTION}

Information on the influence rice price is important for food policy in Indonesia since rice is the staple food [1]. However, there are problems with government policy. Reducing rice prices to make it more affordable could threaten food security and impact the price of paddy. If rice prices are low, the price of paddy will be low too and rice farming will not be profitable. Thus, many farmers will leave paddy farming. However, policies to increase rice prices would harm most people in Indonesia since rice is the main food, and poor people would suffer.

This research is an extension of previous research [2]. The previous findings were only for large and medium farmers, for whom the prices of rice affect the price of paddy. But for small farmers, rice prices have no effect on the price of paddy because the structure of the market is close to a monopsony. The influence of rice price on paddy price is proportional for large farmers, which means the increase of rice price leads an almost equal rise in milled paddy price. However, the relationship for medium farmers is disproportionate, with one percent increases in the price of rice resulting in increases of 0.62 percent in paddy prices.

The previous research was conducted in only one district and cannot represent other regions in Indonesia. However, in 2006, the Ministry of Agriculture of the Republic of Indonesia 
started distributing daily data on the prices of rice and milled paddy on their website. The can be used to analyze the effects on a national scale. This research uses data from January 1, 2007, until December, 31, 2014.

The section discusses the analysis plan. The analysis was done through a simple linear regression and correlation. Section 3 discusses the cointegration analysis, which was used because the price of milled paddy is also influenced by historical prices, and this phenomenon cannot be analyzed by a simple linear regression. Finally, a discussion and conclusions are presented.

\section{ANALYSIS METHOD}

The analysis methods used in this research are regression, correlation, and cointegration. Regression analysis was first used to measure the influence of prices, and correlation was used to measure the integration. Influence is the dependency a dependent variable (the price of milled paddy) on an independent variable (the price of rice) [3]. The regression analysis determines how much the price of rice will increase the milled paddy price. The model used in this analysis is:

$$
\operatorname{Pp}=\mathrm{a}+\mathrm{b} \operatorname{Pr}+\mathrm{u}
$$

where $P p$ is the price of a milled paddy, $a$ is a constant, $b$ is a coefficient of the proportion of increase in rice prices due to the rising price of milled paddy , $\operatorname{Pr}$ is the price of rice, and $u$ is a residual variable. The price of rice otherwise affects the price of milled rice when the probability of acceptance $\mathrm{H} 0$ is $<0.05$.

Correlation analysis is commonly used to measure integration [3]. Variables affect each other in integration, and correlation analysis cannot measure the level of influence. Nevertheless, correlation analysis is still required because in reality, the prices of rice and milled rice affect each other.

The next analysis is more complex, which is required because past prices influence the price of milled paddy. Thus, it is necessary to analyze the data with a time series, but milled paddy price data is not available in this form because sales transactions do not occur every day for milled paddy. Milled paddy sales transactions generally occur after harvest. Thus, the existing daily data can only be analyzed with regression and correlation. To analyze the data as a time series, the data must be merged across time and location. This involves combining daily data into monthly average data. between throughout Indonesia.

An Error Correction Model (ECM) was then used to analyze cointegration. ECM can be used to analyze the cointegration of two variables [4]. The ECM equation was modified from Gujarati and Porter [4] and adapted to the context of this research:

$$
\Delta P_{p, t}=\alpha_{o}+\alpha_{1} D P_{r, t}+\alpha_{2} u_{t-1}+\varepsilon_{t}
$$

The data $u_{t}$ can also be used to test whether the data is stationary or non-stationary. ECM requires analysis of the data in a stationary form. Testing for whether the data is stationary is done using the Augmented Dickey Fuller (ADF) test. $\varepsilon_{t}$ is a residual variable. The equation was calculated using Eviews software, which is a statistical program for econometric analysis. Data were obtained for the daily prices of medium-quality rice and milled paddy in cities and districts throughout Indonesia [5]. According to the Central Bureau of Statistics of Indonesia, 
there are 413 districts in Indonesia and 98 cities [6]. However, price data are not distributed for every day and every district or city since sales transactions do not occur every day.

\section{Simple Analysis}

\section{RESULTS}

The number of data points was 47,842 . The data were analyzed using SPSS software. The data are divided by year to see the effects of changes from year to year. The analysis results are shown in table 1.

Table 1. Values Of Regression and Correlation of The Prices of Rice With Milled Paddy in Indonesia Between 2007 to 2014

$\begin{array}{llll}\text { Year } & \text { Regression } & \text { Correlation } & \text { Significant } \\ 2007 & 0.2754 & 0.5802 & * * * \\ 2008 & 0.2665 & 0.5183 & * * * \\ 2009 & 0.4048 & 0.4414 & * * * \\ 2010 & 0.4457 & 0.4171 & * * * \\ 2011 & 0.3052 & 0.5506 & * * * \\ 2012 & 0.2343 & 0.3583 & * * * \\ 2013 & 0.2654 & 0.4308 & * * * \\ 2014 & 0.3572 & 0.6040 & * * *\end{array}$

***: very significant $\alpha<0.01$

The table shows the important numbers only. The effect is the regression coefficient value, which shows how large the proportion of the increase in the price of milled paddy is when rice prices rise by one unit. The value of these effects appears to change every year, but all values are below 0.5 . This means that the increase in the price of rice was not proportional to the increase in the price of paddy. The integration value is a correlation value, which changes every year, but all values are very significant. It can be concluded that the price of rice has integration with the price of rice paddy.

Next is the analysis of the influence and integration in areas of Indonesia. The analysis cannot be done for all regions in Indonesia because there is too much data to include in this paper. Therefore 20 regions are presented in the table. Regional selections are based on the most number of data available, since more data result in a more accurate analysis. The SPSS results are shown in the following table. 
Table 2. The influence and integration of rice and paddy prices in the regions in Indonesia

$\begin{array}{llllll}\text { No. } & \text { Region } & \text { Regression } & \text { Correlation } & \text { Significant } & \text { Number Data } \\ 1 & \text { Tapanuli Selatan } & 0.4433 & 0.9192 & * * * & 1761 \\ 2 & \text { Karawang } & 0.5615 & 0.8332 & * * * & 1083 \\ 3 & \text { Bandung } & 0.5200 & 0.9408 & * * * & 1011 \\ 4 & \text { Tanggamus } & 0.4275 & 0.9281 & * * * & 886 \\ 5 & \text { Kulon Progo } & 0.4930 & 0.9711 & * * * & 873 \\ 6 & \text { Jember } & 0.4827 & 0.9237 & * * * & 828 \\ 7 & \text { Hulu Sungai Utara } & 0.7368 & 0.9650 & * * * & 800 \\ 8 & \text { Agam } & 0.7378 & 0.8977 & * * * & 759 \\ 9 & \text { Majalengka } & 0.5367 & 0.9413 & * * * & 759 \\ 10 & \text { Subang } & 0.5739 & 0.8973 & * * * & 745 \\ 11 & \text { Ngawi } & 0.5041 & 0.9181 & * * * & 735 \\ 12 & \text { Indramayu } & 0.5356 & 0.9355 & * * * & 637 \\ 13 & \text { Asahan } & 0.4209 & 0.8688 & * * * & 618 \\ 14 & \text { Lampung Selatan } & 0.4557 & 0.9249 & * * * & 600 \\ 15 & \text { Sleman } & 0.4883 & 0.9329 & * * * & 582 \\ 16 & \text { Kupang } & 0.0160 & 0.0766 & 0.0608 \\ 17 & \text { Sopeng } & 0.5273 & 0.9538 & * * * & 573 \\ 18 & \text { Lamongan } & 0.9429 & * * * & 563 \\ 19 & \text { Kuningan } & 0.4595 & 0.4846 & * * * & 542 \\ 20 & \text { Badung } & 0.2820 & 0.7143 & * * * & \end{array}$

The table shows that the influence and integration vary in each region. In general, rice prices affect the price of milled paddy significantly. In the area of Kupang only, rice price has no effect on the price of paddy at a 95\% confidence level. The different value of regression in this area will be the subject of future study on the factors that affect integration between the price of paddy and rice. This research only focuses on whether there is price integration in Indonesia

\section{Advanced Analysis}

The advanced analysis was conducted using cointegration analysis. The fluctuation of the prices of rice and milled paddy can be seen in figure 1 . The figures show that the price of milled paddy is always integrated with the price of rice. If the rice price increases, the price of milled paddy increases. 


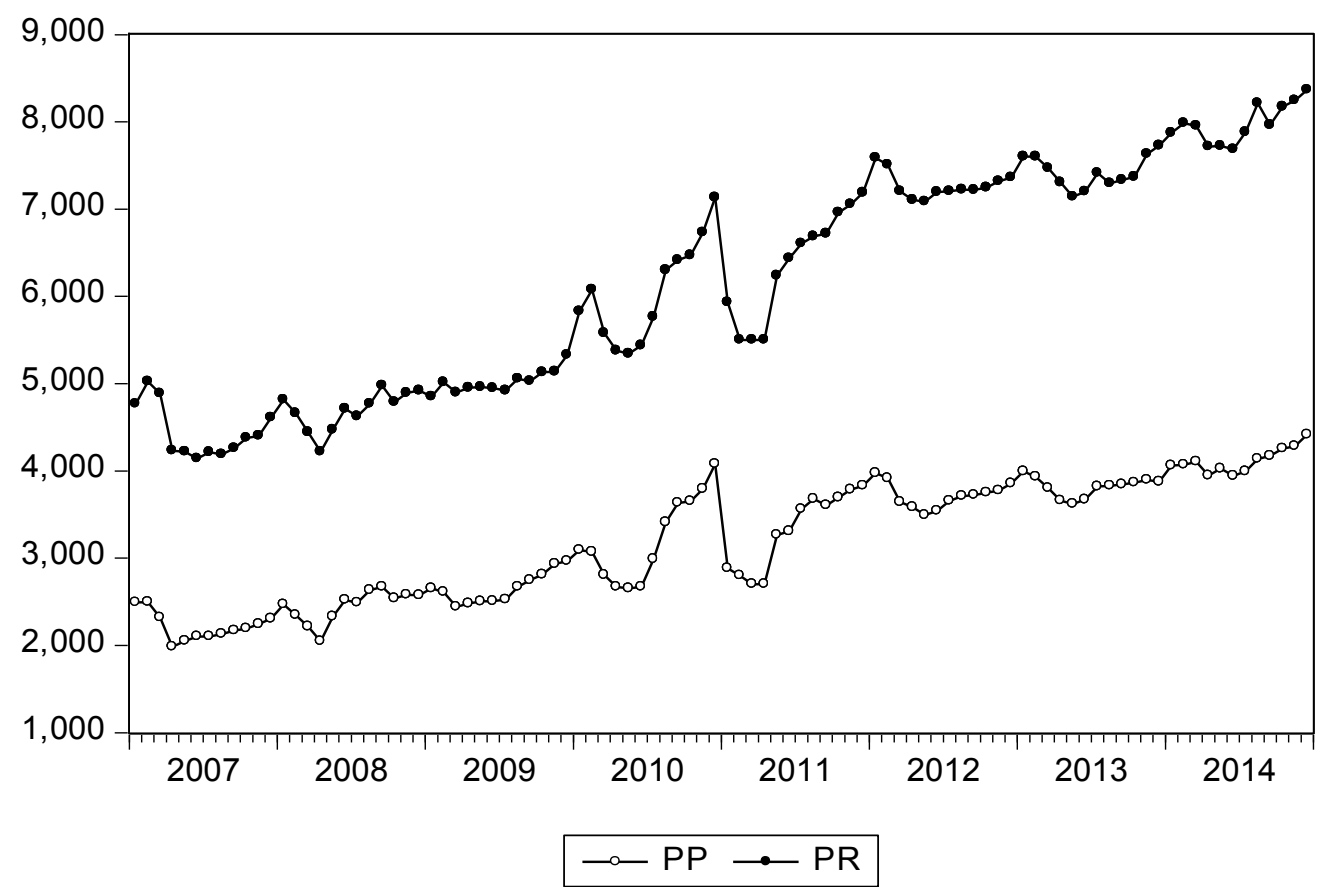

Figure 1. The price of rice and milled paddy prices in Indonesia.

Table 3. Test unit root

\begin{tabular}{|l|c|c|c|}
\hline & & t-Statistic & Prob.* \\
\hline & & & \\
\hline Augmented Dickey-Fuller test statistic & -6.082198 & 0.0000 \\
\hline Test critical values: & $1 \%$ level & -3.503049 & \\
\hline & $5 \%$ level & -2.893230 & \\
\hline & $10 \%$ level & -2.583740 & \\
\hline
\end{tabular}

Table 4. Results of cointegration analysis.

\begin{tabular}{|c|c|c|c|}
\hline & Trace & 0.05 & \\
\hline Eigenvalue & Statistic & Critical Value & Prob.** \\
\hline 0.284037 & 31.09868 & 15.49471 & 0.0001 \\
\hline
\end{tabular}

Table 4 shows the statistical trace values that exceed the critical value, so the probability of acceptance $\mathrm{HO}$ is $<0.01$. Thus, the conclusion is that there is cointegration at a level below $1 \%$. The effects of rice price and previous price from ECM are shown in table 5.

Table 5. The results of ECM

\begin{tabular}{|c|r|r|r|r|}
\hline Variable & Coefficient & Std. Error & t-Statistic & Prob. \\
\hline C & -5.989594 & 8.268207 & -0.724413 & 0.4707 \\
\hline D(PR) & 0.686608 & 0.034125 & 20.12055 & 0.0000 \\
\hline ET(-1) & -0.352627 & 0.069309 & -5.087752 & 0.0000 \\
\hline
\end{tabular}


The table shows that the effect of the price of rice (D(PR) and previous prices (ET (-1)) on the price of milled paddy is very significant. This is evident from the value of the probability of acceptance $\mathrm{HO}<0.01$. Thus, the conclusion is that milled paddy prices have integration with the price of rice. The influence value of the price of rice was 0.68 , indicating that an increase in rice price by one unit will be followed by of price increase of milled paddy by 0.68 units. The increase is not proportional, and the percentage increase in the price of milled paddy will be lower than the increase in the price of rice.

\section{DISCUSSION}

The results show an integration effect of the price of rice with the price of milled paddy in Indonesia. The influence varies from year to year and between regions, but all the regression coefficient values are less than one. The price increases are disproportionate, and the increases in rice price may not increase the family income of paddy farmers.

A previous study explains how price increases were not proportional to increases in the price of milled paddy based on the effect of the market structure on the integration [2]. In the market for milled paddy, there are two opposing main structures: a perfectly competitive market structure and a monopsony market structure. The effects of the price of rice on milled paddy prices are illustrated in figure 2 .

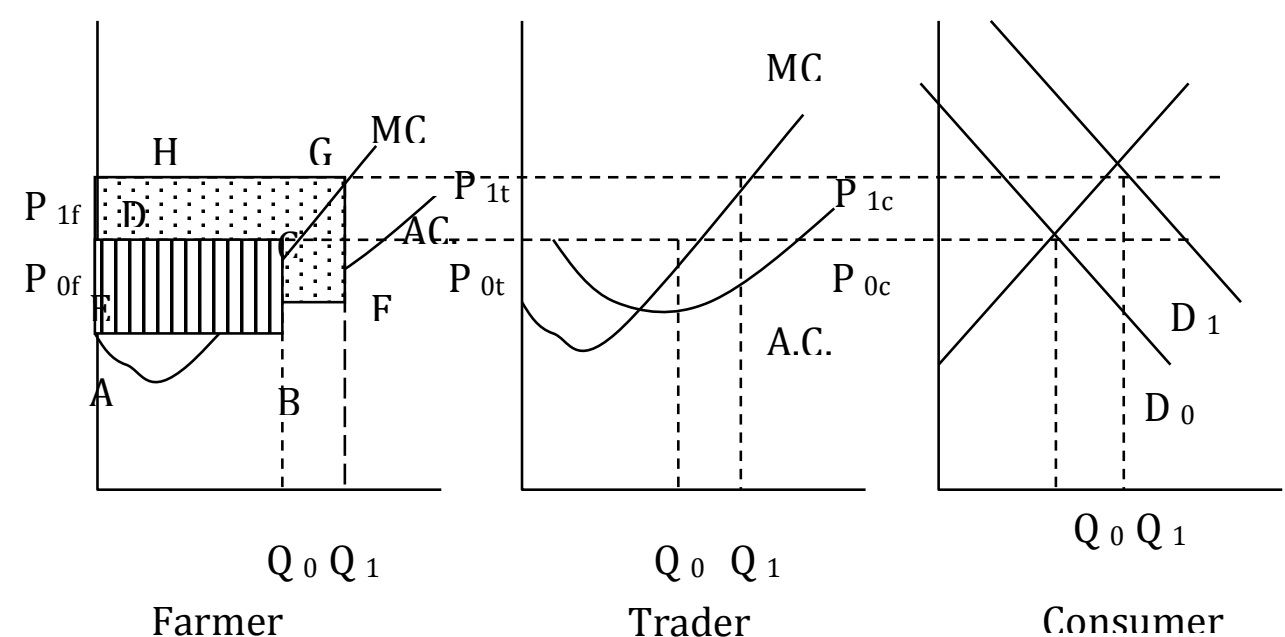

Figure 2. Effect of increases in the price of rice on milled paddy price) in a perfectly competitive market [2].

In this figure, all variables are constant except for changes in prices and profits of farmers. If the demand for rice increases from $\mathrm{D}_{1}$ to $\mathrm{D}_{0}$, the rice price changes from $\mathrm{P}_{0 c}$ to $\mathrm{P}_{1 \mathrm{c}}$. With rising prices, a trader will buy rice with a proportional increase in prices at the farm level of $\mathrm{P}_{1 \mathrm{f}}$ to $\mathrm{P}_{2 \mathrm{f}}$. This is due to the absence of a market barrier in a perfectly competitive market, where many other merchants come and compete with the traders to buy milled paddy from farmers. Due to the proportional increase in the rice price, the profit of the farmers will be changed from rectangle $A B C D$ to rectangle EFGH. Thus, the conclusion is that proportionate price increases will improve the profitability of paddy farming.

A monopsony situation is different from a market with perfect competition because there is a strong barrier for other traders to enter the market. The effect of increases in the price of rice for milled paddy prices in a monopsony market can be seen in figure 2 . 


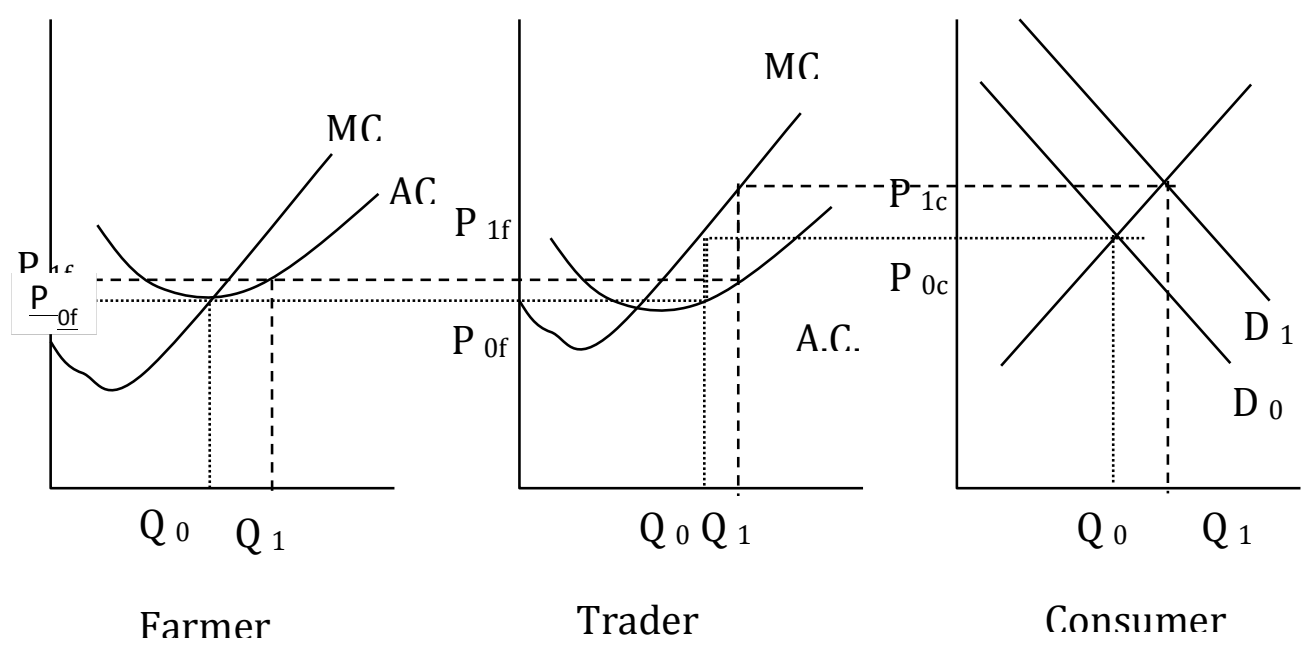

Figure 2. Effect of increase in the price of rice on milled paddy prices in a monopsony market. [2]

In a monopsony market, there is only one trader in the area who can buy milled paddy produced by farmers. Traders will maximize profits by buying paddy for the average production cost (AC) of the farm. At that price, the farmer will still sell if the price is not lens than the average production cost (AC). Farmers cannot obtain a higher price because there are no other traders. If there is an increase in rice prices in the consumer market from $\mathrm{P}_{0 c}$ to $\mathrm{P}_{1 \mathrm{c}}$, then traders will only raise prices along the curve of AC for farmers. Thus, the increase in the price of rice will not be proportional to the increase in the price of milled paddy.

However, there is no truly competitive market or perfect monopsony market. The market structure has degrees of monopsony markets, such as oligopsony and oligopsonistic competition, which extend to near perfect competition. When approaching perfect competition, price rises in milled paddy will be proportional to increases in the price of rice, but when approaching a monopsony market structure, the increase will be more disproportionate. Proportional increases will increase farming profits, while disproportional increases will not increase profits.

In the case of integration of the rice price with the price of milled paddy, there will be an increase in the income of family farms if the rice price increases, but not if there is no integration. Research result of Makbul [2] divided farmers into three groups: large farmers, medium farmers, and small farmers. Large farmers have more than one hectare of land, medium farmers have between one-half and one hectare, and small farmers have less than half a hectare. The results showed that the large farmers experienced a significant influence of increases in rice price on the price of milled paddy with a regression coefficient of 1.03. Thus, the increase is proportional. Large farmers are in a competitive structure where farmers can sell to every trader anywhere they want. The research shows that large farmers benefited from increases in the price of rice, and family income increased significantly.

Among middle farmers, the increase in rice prices significantly influence the price of milled paddy, but the regression coefficient is 0.62 . This suggests that the increase is not proportional, so farmers experience a more monopsonistic market structure or monopsonistic competition. In this case, traders have limited power to determine price. The results showed that an increase in the price of rice will increase farm family incomes significantly. However, for small 
farmers, increases in rice price have no significant effect on the price of milled paddy. The results showed no significant effect of the increase in the price of rice on the family income of farmers. This happens because small farmers rely heavily on merchants, who can thus determine the purchase price of milled paddy from farmers. The structure of this market is a monopsony structure. The results of an agricultural census in 2013 indicated that 57 percent of farmers in Indonesia are small farmers [7]. Thus, for more than half of rice farmers in Indonesia, family incomes do not increase when the price of rice increases.

According Mubyarto [8], small farmers often practice ijon, which means that farmers sell paddy before it is harvested. Usually farmers do this because they have financial problems and request a loan from a merchant. The traders will help farmers with financial problems, but it is the traders who determine the price of milled paddy. This phenomenon is a type of monopsony market. Furthermore, the reduced role of Bulog (the Indonesian Bureau Logistics) in stabilizing the price of rice has led to the emergence of an oligopsonistic market [9]. Bulog is a government organization that helps stabilize rice prices in Indonesia, and its role diminished after the reform of governance in Indonesia in 1998. Furthermore, rice traders have taken over their role. Some wholesalers of rice predominantly cooperate to perform vertical and horizontal integration in the rice economy. Vertical integration involves combining business of purchasing paddy, paddy processing into rice, and rice sales in a cooperating group. Horizontal integration involves cooperation in the rice trade between traders who already know each other and have a kinship between them [9]. The activities of the rice traders have formed a cartel oligopsony.

This study did not show an increase in rice farming profits or increasing the income of farm families. Importantly, if there is no increase in rice farming profits, farmers will leave paddy farming and switch to other businesses. If this situation continues, it will threaten food security in Indonesia. Food security in this matter means that the government has the authority to meet the food needs of the people of Indonesia with its own resources [1]. Food security is important because of food safety concerns. If food security is neglected and the country becomes dependent on food imports, food security will be threatened when there is turmoil in the international rice market. According to Anderson and Strutt [10], China's state dependency on food imports has contributed social unrest in the country.

Food policy is aimed at increasing the price of rice to give farmers the incentive to continue paddy farming and maintain food sovereignty. However, such policy can increase poverty in Indonesia. According to Pfeiffer [11], an increase in the price of rice in Indonesia by 10 percent would increase poverty by four percent, and an increase by 30 percent would increase poverty by 14 percent. McCulloch [12] concluded that an increase in the price of rice will lead to an increase in urban and rural poverty, and even for small paddy farmers. According to Syafaat [13], for small farmers, only 26.5 percent of their income is from farming, and the rest is from other businesses. Furthermore, 70 percent of poor households are spending money to buy rice [14]. Thus, for poor farmers, a rice price hike will lead to an increase in the cost of living. Government policy to reduce food prices will also increase productivity in the agri-food sector. According to Dorward [15], low food prices will increase the growth of the broader economy, which in turn will increase the productivity of workers in the agricultural sector, especially small farmers.

Government action is thus required to address this dilemma. If the government desires food security, the price of rice should be increased, but this will increase poverty. To provide an incentive to farmers to continue farming, the price increases of paddy should be proportional to the increase in rice prices. Research is needed to explore factors that affect the proportionality of increases in rice price to the price of milled rice. If the monopsony market 
structure is one such factor, a program will be needed to reduce this structure in the paddy market.

Bulog managed to stabilize the price of rice in Indonesia through the ceiling and floor prices [18]. Bulog can reduce the monopsony market structure in the rice market by providing a competitor against traders who have a monopsony in the paddy market. If the price increase is not proportional to the milled paddy price increases, then Bulog could buy milled paddy from farmers with an increase similar to the increase in the price of rice. In microeconomic conditions, Bulog will not have a financial loss, but in macro conditions, it will generate major economic benefits for the economy of rice in Indonesia. The benefit is that farmers have the right to benefit from increases in rice prices, which will be an incentive to farmers to increase production. Increased rice production will support food security in Indonesia.

In reality, it is not easy to implement this concept, and many unforeseen problems could arise. Changes in the price of rice are ever-changing and difficult to ascertain, but through the experience of Bulog, some adjustments can be made, such as accepting small profits to reduce the risk of price changes. In this case, it is possible to accept a reasonable profit but not to maximize profit. The purpose of such a program is not to maximize profits but to help farmers receive fair prices in accordance with increases in rice price. Furthermore, implementation of this program would not be carried out for all regions, but only in areas were monopsony practices occur.

\section{CONCLUSION}

The research results indicate that the price of rice integration with and has a significant influence on the price of milled rice in Indonesia. Nevertheless, increases in rice price are not proportional to the increase in the price of milled paddy. The increases milled paddy prices are always lower than those of rice. This means that the price increases are mostly enjoyed by others who seek to profit from economic rents. If the government desires food policies to achieve food security, high rice prices are necessary but result in increased poverty. However, if the price increase is not entirely up to the farmers, then such policies will be futile, and food security will be difficult to accomplish.

\section{References}

[1] Bulog. (2015). Ketahanan Pangan [Food security]. Retrieved 9 8, 2015, from Badan Urusan Logistik [Logistics Agency]: http://www.bulog.co.id/ketahananpangan.php

[2] Makbul, Y., Pradono, Ratnaningtyas, S., \& Dwiyantoro, P. (2015). The effect of Market structure on the integration of rice prices with paddy prices and its impact on farmers family income in the Kroya district, indramayu regency, Indonesia. Journal of Developing Area, 49(3), 217-228. Retrieved 32 2, 2016, from https://muse.jhu.edu/issue/32433

[3] Granger, C., \& Elliot, C. (1967). A fresh look at wheat prices and markets in the eighteenth century. Economic History Review, 20, 257-265.

[4] Gujarati, D., \& Porter, D. C. (2009). Basic Econometrics. New York, USA: McGraw Hill.

[5] Kementan. (2015). Laporan Harian Harga Produsen Komoditas Pangan Tingkat Kabupaten/Kota [Daily Reports Manufacturers Food Commodity prices at Regency / City]. Retrieved 12 31, 2015, from Kementerian Pertanian Republik Indonesia [The Ministry of Agriculture of the Republic of Indonesia]: https://aplikasi.pertanian.go.id/smshargakab/lhk01.asp 
[6] BPS. (2016). Jumlah Kabupaten di Indonesia Menurut Propinsi [The number of districts in Indonesia by Province]. Retrieved 4 2016, 2016, from Badan Pusat Statistik [Central Bureau of Statistics]: https://www.bps.go.id/linkTableDinamis/view/id/853

[7] BPS. (2013). Sensus Pertanian [Agriculture Census]. Retrieved 3 2, 2016, from BPS: https://www.bps.go.id/index.php/publikasi/4411

[8] Mubyarto. (1995). Pengantar Ekonomi Pertanian [Introduction to Agricultural Economics]. Jakarta: LP3ES.

[9] Firdaus, M., Baga, L., \& Pratiwi, P. (2008). Swasembada Beras dari Masa ke Masa [Rice self-sufficiency of the Ages]. Bogor: IPB Press.

[10] Anderson, K., \& Strutt, A. (2014). Food security policy options for China: lessons from other countries. Food Policy, 49(1), 50-58. doi:http://dx.doi.org/10.1016/j.foodpol.2014.06.008

[11] Peifffer, K. (2013). Volatile Rice Price. Influence on Indonesia's Domestic Market. Berlin: Humblot-Universitat Zu Berlin.

[12] McCulloch, N. (2008). Rice Prices and Poverty in Indonesia. Bulletin of Indonesian Economic Studies, 44(1), 4563. Retrieved 3 8, 2017, from http://www.tandfonline.com/doi/full/10.1080/00074910802001579?src=recsys

[13] Syafaat, N., Pantjar, S., \& Mardianto, S. (2005). Pertanian Menjawab Tantangan Ekonomi Nasional [Agriculture National Economic Challenge]. Jakarta: Lapera Pustaka Utama.

[14] Zeigler, R. (2005). Rice Research Development: Supply- Demand, Water, Climate, and Reasearch Capacity. In B. Krisnamukti, Revitalisasi Pertanian dan Tarian Peradaban [Revitalization of Agriculture and dance Civilization]. Jakarta: Kompas.

[15] Dorward, A. $(2013,4)$. Agricultural labour productivity, food prices and sustainable development impacts and indicators. Food Policy, 39, 40-50. doi:10.1016/j.foodpol.2012.12.003 